Article

\title{
It's All in the SKU: Getting Food from Somewhere from the Field to the Dinner Plate while Using a Large Scale Retailer
}

\author{
Carolyn M. Haythorn ${ }^{1}$, Daniel C. Knudsen ${ }^{2}$, James R. Farmer ${ }^{3, *}$, Carmen C. Antreasian ${ }^{2}$ and \\ Megan E. Betz ${ }^{2}$ \\ 1 Department of Anthropology, Indiana University, Bloomington, IN 47405, USA; cmhaytho@iu.edu \\ 2 Department of Geography, Indiana University, Bloomington, IN 47405, USA; knudsen@iu.edu (D.C.K.); \\ cantreas@iu.edu (C.C.A.); mebetz@iu.edu (M.E.B.) \\ 3 School of Public and Environmental Affairs, Indiana University, Bloomington, IN 47405, USA \\ * Correspondence: jafarmer@iu.edu; Tel.: +1-812-856-0969
}

Received: 8 January 2019; Accepted: 5 February 2019; Published: 9 February 2019

check for

\begin{abstract}
The local food movement provides sustainable food, but often suffers from a lack of economic viability. We examine the need for concerned consumers, qualified growers, and responsible retailers. Concerned consumers are individuals who desire food from somewhere, but must shop at food retailers. Qualified growers sell sustainable food from somewhere, and must be able to set their own prices. Responsible retailers provide consumers with food from somewhere. Taken together, currently there is no good system in place to allow for large scale purchases and long term sales of food from somewhere for a retailer. To solve this, we propose a benevolent wholesaler model, in which stock keeping unit (SKU) numbers are given to each type of product from each farm. This enables tracking of the origin of the produce by retail customers and individual consumers, while retaining the attributes of a food system that allow for large scale purchases and long term sales. Such systems are no less sustainable, but potentially provide enhanced economic viability for producers.
\end{abstract}

Keywords: enabling food from somewhere; benevolent wholesalers; stock keeping units (SKUs)

\section{Introduction}

Philip McMichael [1] (p. 147) states, 'Just as the dynamics of the previous [food] regimes centered on tensions between opposing geo-political principles ... so the corporate food regime embodies a central contradiction between a "world agriculture" (food from nowhere) and a place-based form of agro-ecology (food from somewhere).' Propagating food from nowhere, the divorcing of food from the land on which it grows, is in the best interest of massive corporate monopsonists who provide the bulk of our food, which allows them to keep production costs low and profits high. Yet, this same strategy also creates an opposing tension, 'including a counter-mobilization in the name of "food sovereignty"'; and 'various forms of localism ... such as ... Slow Food, Community Supported Agriculture, and small-scale organic producers' [1,2].

Counter-mobilization effects can be seen in many emerging food-ways, which allow local and sustainable foods to enter the market. This is particularly true for small quantities of food: from farmers' markets, to grocery stores, to companies that deliver food directly to a customer's doorstep. Many paths exist for local food distribution to individuals, these are termed alternative food networks [3]. Nevertheless, there are many problems with this newfound emphasis placed on local foods. 
Stahlbrand suggests that, "the paradox of the value-based food chains (VBFC) conceptualization is that small and mid-size farmers- the least powerful and most price disadvantaged players in the food system - are increasingly the ones being asked to shoulder costs of environmental and social protection through their production practices" [4] (p. 269). These small and mid-size producers assume the true costs of sustainable production, compared to large-scale producers, and are placed at a disadvantage in the market place due to charging higher prices [4]. A central question becomes, "are local food based systems an avenue that might allow small and mid-size producers recoup the true costs of sustainable production"?

Secondly, there is considerable disagreement regarding what qualifies as local [5]; by definition, local is delineated by 100-mile radii outlining the distance between farms and the retail establishments. According to the 2008 Farm Act, 'local' is food that is sold within 400 miles of its origin, or within the same state where it was grown [6]. For large scale food providers, 'local' can be a much wider region, often covering multiple states. Even if a clear range for the origin of local food is defined, the term remains problematic [1]. Beyond distance, many aspects factor into consumers' definition of local. Robinson and Farmer summarize that local food has a deeper meaning which implicates time (from field to plate), health and nutrition, operational scale, accountability, environmental stewardship, systems thinking, and an oppositional approach to consumption, all of which are embedded with the public's quest to access nearby food [7].

Third, much of the 'infrastructure of the middle' is now absent from agricultural and food landscapes, apart from those controlled by large, multinational food corporations [7]. Such entities set the rules, such as terms and prices, packaging and labeling requirements, in addition to varieties and quantities [4]. Altogether, "these corporations have the power to demand supply chain relations that work best for them, whether or not these arrangements work for farmers, the community, or the environment" [4] (p. 270).

Terminology and logistics aside, eating exclusively local food is simply impractical without major behavioral changes [8]. In large cities, even if it was possible to procure enough local food to feed all the inhabitants all year-long, it would almost certainly result in a wide variety of foods being completely inaccessible to locavores, at least not without the extensive use of greenhouses and hydroponic methods that would surely undermine the movement's mission. The seasonality of various products would also make for a fairly limited diet during much of the year, particularly in regions outside the tropics. Additionally, the local food movement is problematic in that the lives of small farmers are often tenuous. Martha McMahon [2] (p. 117, 130) writes:

\section{In [British Columbia] the turn to local does not appear to have improved the situation for a majority of small farmers. The number of farmers in the province fell from 21,835 in 1996 to 19,759 in 2006 ... Drawing on lessons from feminist social organizing from which we learned that simply celebrating or validating women and "womanly ways" was an inadequate social justice strategy, we can see that celebrating local food and small farmers, or simply affirming people's (the poor in particular) right to adequate, safe, nutritionally or culturally appropriate food is also inadequate. The subject-positions of both farmers and consumers (including the poor's) are left untransformed.}

Clearly, a change is needed in how mobilizations against corporate regimes, 'food from nowhere', take shape. Our study argues that rather than creating new alternative food networks, we need to focus on modifying the existing corporate food ways so that food from somewhere-not merely 'local' food-is more readily accessible to the average consumer. We propose that the best way to do this is through benevolent wholesalers—an innovative supplier as Stahlbrand might label it [4]—capable of providing food-from-somewhere to consumers using the same mechanisms that typical wholesalers today use to provide food-from-nowhere. This will allow consumers using a large food retailer for the majority of their daily caloric intake to have access to provenance-laden food without drastically changing how they access food, or how food is being sold. Before discussing the benevolent wholesaler system, we first discuss some methodological considerations and the need for both consumers and 
growers, before examining other mechanisms a retailer may use to purchase food that they sell to a customer.

\subsection{The Needs of a Consumer-Food from Somewhere}

The core problem addressed in our paper is: how can we get food-from-somewhere to individuals who rely on large retailers for the majority of their food? Certainly, one may argue that there are many consumers using large retailers who are not interested in the origin or quality of their food. However, an increased emphasis placed on nutritional education, as well as an increase in programs emphasizing knowing a food's origin and sustainability, such as the Real Food Challenge [9,10], has led us to conclude that there are many consumers who care about their food, but are at the mercy of the retailer who provides them with food that satisfies their needs. In order to understand their problem, we first examined the needs of these consumers who are concerned with the origin and quality of their food, and who rely on a large food retailer for most of their daily food consumption. For these concerned consumers, their needs are as follows:

1. Food security. Concerned consumers need reliable access to healthy and culturally appropriate food, which they can afford [8,11]. We propose that using a food retailer can increase a concerned consumers' food security, as they can be sure that the food will be available to them, and there are strategies in place, which help ensure that they are able to afford it.

2. Sustainably and fairly grown food. Concerned consumers need access to food that is sustainable, does not harm the environment, and is produced using fair labor practices [12].

3. Food-from-somewhere. Food-from-somewhere is food of known origin to the consumers [13,14]. This means that consumers know where the food was grown, how it was grown, and who grew it [15]. The more information that is known about the food, the more substantial the 'somewhere' becomes, and the better it is for concerned customers. It must be food-from-somewhere rather than simply 'local' food, because the word 'local' says nothing about how the food was grown, or, given the fact that a clear definition of local has yet to be agreed upon among those involved in the food system, where the food was grown. Thus, a consumer has good reason to remain concerned about food that is simply labeled local, because they effectively know nothing about the food. When food is not from somewhere, it is from nowhere [1].

4. Food sovereignty. Defined as, 'the right of the peoples to define their own agriculture and food policies, to protect and regulate domestic agricultural production, and trade in order to achieve sustainable development objectives, to determine the extent to which they want to be self-reliant, and to restrict the dumping of products in their market' ([16] as cited in [1]; (p. 147)), food sovereignty gives individuals and individual communities the agency to choose what food to eat and where to get it from. Purchasing food from a retailer inherently limits some of the sovereignty that consumers have because they must rely on the retailer to provide them with food. It is our job to determine how to provide the most sovereignty possible within a retailer to individual relationship. Allowing concerned consumers to have food sovereignty in a retailer to individual relationship can provide an effective channel through which food-from-somewhere can exist in the corporate food regime.

5. Responsible retailer. Given the fact that concerned consumers are to a large extent at the mercy of large retailers, the responsibility rests on the retailer to provide consumers with food which meets the above requirements as much as possible. Although we defined food-from-somewhere simply as food whose origin is known, we will henceforth use it to mean food that meets all the requirements for concerned consumers-that is, food that is grown sustainably, and whose origin and conditions under which it was produced are known. Thus, a responsible retailer must provide consumers with food-from-somewhere. 


\subsection{The Needs of Food Producers and Food Retailers}

Points 1-4 of a concerned consumer's needs deal with the type of food they are provided. If these consumers were not using a large retailer, they could probably meet all these needs by shopping at a farmers' market, or food hub. Thus, it is point 5 that highlights the problem concerned consumers face: they are constrained by the fact that they must use a retailer. For consumers, there are two intermediaries involved in getting food-from-somewhere from the producers onto their plates. While the second intermediary is the retailer, it is the first we seek to uncover in this paper. This first intermediary must mediate between the needs of a food producer and a food retailer. In order to determine what the intermediary should be, we first must determine what producers' and the retailers' needs are.

First, we examine the needs of food producers. In order to meet the needs of concerned consumers, producers must be transparent about their growing methods and sustainably, ensure food sovereignty, and be from the same region as the retailer and the consumers of the food when possible, i.e., they must grow food-from-somewhere. We will call these growers, 'qualified growers.' While some qualified growers' needs correspond with the needs of growers in general, a few are specific to growers of food-from-somewhere. According to an early 2010 report from a southern Indiana food and farming organization, the Local Growers' Guild, these qualified growers need:

1. The ability to set their own prices. While food-from-nowhere can be grown on a large scale- unsustainable farms grown at great distances-qualified growers often cannot compete with their low price per food item $[4,16]$. Qualified growers need to be able to set their prices at a rate they can afford, which is generally higher than the price of food-from-nowhere, in order to continue providing consumers with food-from-somewhere.

2. Marketing/advertising. If consumers do not know who the grower is, they cannot buy from them. Qualified growers must either budget time to do their own marketing and public outreach, or budget money to pay someone to do it for them.

3. An identity. A qualified grower cannot grow food-from-somewhere if they do not have an identity, as having an identifiable origin is a primary tenet of food-from-somewhere [14,15].

4. Transportation for their product. Consumers generally do not travel to a grower's farm to purchase their produce. Thus, growers must either transport their own goods, which is time consuming and costly, or pay someone to transport their goods for them.

5. Adequate food storage. Growers must be able to store the food they grow until they are able to sell it. The amount of storage they have affects how large their growing operation can be, as well as how long their season must be, in the sense that a longer growing season can compensate for less storage.

Next, we looked at the needs of food retailers. These needs apply to all food retailers, regardless of whether they provide individuals with food-from-somewhere or food-from-nowhere. Food retailers' needs:

1. Large quantities of food. They are responsible for providing food to large numbers of people, and will go out of business if they are unable to do so.

2. Consistent and reliable food. Retailers are responsible for providing consumers with food on a regular basis. They will be held accountable if they are unable to provide consumers with food, regardless of whether the weather in the area destroys local crops, or someone outbids them at an auction.

3. Extended seasons. In general, consumers using large retailers expect certain crops year round, regardless of the food's regional growing season. Thus, retailers must have a way to extend the season of the food they provide.

4. Insurance and good agricultural practices (GAP) certification for all their suppliers. Retailers are also put at a risk if they use growers who are not GAP certified, or do not have enough insurance. 
However, the paperwork required for proper coverage is time consuming and the insurance can be expensive; this acts as a barrier to entry for many suppliers to work with a retailer.

5. Food delivered to them. While in theory a retailer could go pick up food from their supplier, in general, they do not. The sheer quantity of food that retailers deal with on a daily basis would make the task of picking up in addition to preparing, packing, and selling the food nearly impossible.

6. As few suppliers as possible. Given the fact that every supplier must be certified, have insurance, and deliver the food to the retailer, it is in the retailer's best interest to have as few suppliers as possible.

\section{Study Area and Methods}

\subsection{Methods}

This research used an ethnographic case study approach [17] to study how food-from-nowhere can become food from somewhere. The majority of the analyses were taken from field notes detailing interviews between the research team and various key informants from across the food system. Our ethnographic field research, which is critical to this work, was completed in these sites prior to the interviews. Furthermore, archival materials were also used to underpin and explain the phenomenon at hand. More specifically, our research team solicited data from 19 individuals/employees that fit into one of five groups: representatives from producers, farmer's market personnel, food hub representatives, produce auction staff, retailer representatives, and wholesalers. We also gathered data while attending community forums that focused on food hub development. Data were thematically analyzed and then coded in conjunction with grower and retailer themes in Section 1.2. Ultimately, our focus turned to the wholesale industry, as they showed the greatest purchasing capability for large-scale retailers. The primary rationale for this move was based on the retailer's needs. The retailer is a large food-service provider, serving approximately 8,100 salads each day during the period of mid-August through mid-May. Other product needs were parallel to salad consumption. Thus, it would take an organization with large capacity for aggregation and distribution to accommodate the daily demand for the retailer.

\subsection{South-Central Indiana Context}

South-central Indiana was our area of study, including Monroe County and the City of Bloomington as the metro-center for the region. Monroe County and Bloomington are home to Indiana University's flagship campus, and corporate headquarters for Cook Medical. The county has nearly 147,000 residents and 55,014 households [18]. The region boasts a strong local-foods scene, with the state's largest farmers' market that garners over 10,000 weekly visitors during the height of market season. To the north is Morgan County that separates Monroe from the Indianapolis metro. To the east, south, and west lay rural counties with populations of $15,000,45,000$, and 32,000 residents, respectively [19]. Further south and west are multiple Plain communities, with sizeable Amish populations in Orange, Davies, and Dubois Counties. Amish communities are critical as they are among the state's largest fruits and vegetable producers with capacity for aggregation and distribution. Plain communities are common throughout Indiana, the Midwest, and the Great Lakes states [20]. Monroe County and the adjacent regions of bordering counties are characterized with rugged, heavily forested hills, ridges, and valleys. The geology primarily consists of a mix of Harrodsburg limestone and Borden siltstone and shale, with unglaciated thin soils. Farmland becomes somewhat pervasive as one travels 20-40 miles from Bloomington, and beyond (see Figure 1). 


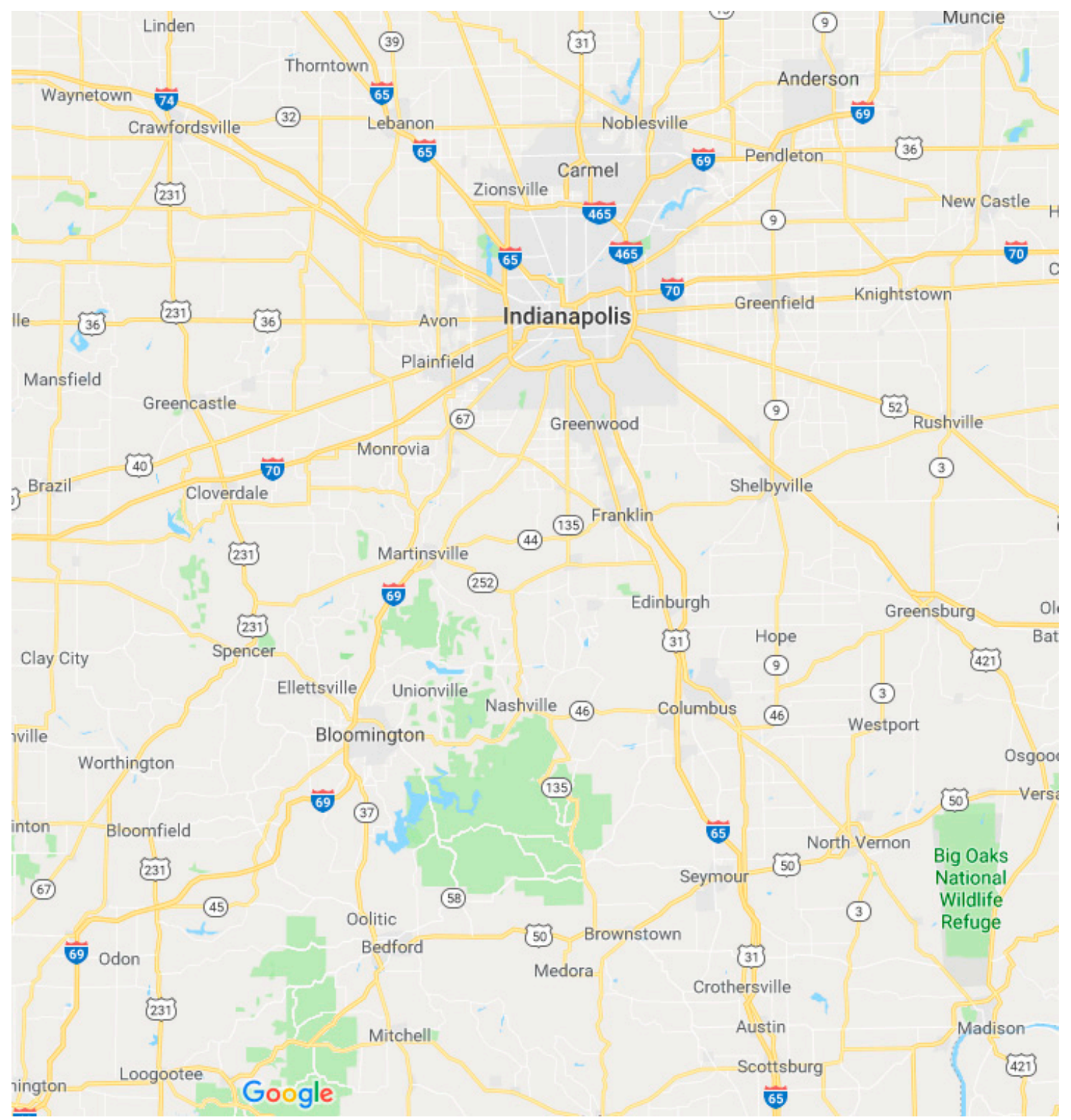

Figure 1. Linked Google instant map of south-central Indiana.

\subsection{Providers and Producers}

Before introducing our argument, there are a few terms which we feel should be clarified for readers. In our discussion, we ran into trouble with the words 'consumer/customer' and "producer/provider." In a grower to distributer to retailer to individual model, there are three potential customers: the distributer, the retailer, and the individual. There are also three potential providers: the grower, the distributer, and the retailer. For this study, we focus exclusively on farmers who grow produce. We do not include livestock farmers for the sake of simplicity-they operate differently than produce growers, and have different needs.

- We use the provider versus customer dichotomy throughout to refer to the small-scale transactions in the food system, either grower versus distributer, distributer versus retailer, or retailer versus individual.

- In turn, we use the word producer to refer only to growers, who actually produce the food, and consumer only for individuals who actually consume the food. 


\section{Findings: from Grower to Retailer}

Understanding the needs of both retailers and producers, we examined the current possible distribution mechanisms to determine which works best as an intermediary between retailers and qualified growers (Figure 2). We studied and interviewed a representative for farmers' markets, auctions, food hubs, and conventional wholesalers.

\subsection{Farmers' Markets}

Farmers' markets serve qualified growers the best, because the growers are generally physically at the market, it is easy for them to set their own prices, and to maintain an identity with consumers by interacting with them directly. Little food storage is needed, because the grower generally does not bring more than a week's worth of produce to the market. Marketing and transportation is the responsibility of the grower-meaning it is up to them to decide how best to market their produce (including packaging), and what they need to do to transport their food. While the grower may not find this convenient, as having someone else do the marketing and transportation, it does provide him or her with the ultimate control over the food they are growing.

However, farmers' markets are the worst option for large retailers. In fact, none of their needs are completely met with a farmer's market. They cannot be guaranteed high quantities of food, because, as stated before, farmers typically only bring a week's worth of their produce to the market, meaning a retailer would effectively have to buy every piece of produce that every grower brings each week in order to possibly meet the amount of food needed. This would not work, because retailers need as few suppliers as possible. Furthermore, being GAP certified and having insurance is not always a qualification for growers at a farmers' market. This would mean that the retailers must perform their own checks to see if growers are certified, and this exposes them to potential risk. In addition, there is no guarantee about what food is going to be produced each week, or if it is going to be produced at all-for example, if a major drought in the area prevented many growers from being able to produce food, a retailer using a farmers' market for their food supply may be out of luck. Farmers' markets are also highly affected by seasonality. Many close during the winter, and there is certainly a wide variety in what is offered at different times of the year. Lastly, there is no mechanism in place for food from a farmer's market to be driven to a retailer. When dealing with such a large volumes of produce all the time, it is simply not feasible for a retailer to pick up and transport their own food. Thus, on all accounts, using a farmers' market to supply food to a retailer is highly inefficient.

\subsection{Auctions}

Auctions can function well for growers, as shown by a previous study where growers were able to sell $75 \%$ of their produce at an auction [21]. The lot number of the produce does allow a customer to locate where the food originated, making it possible to purchase food-from-somewhere should they desire. However, given that the food is auctioned off to the highest bidder, growers cannot set their own prices. Growers must also transport their wares to the auction hall. While packaging and marketing are provided by the auction hall, they are under the umbrella of the auction, not the growers themselves. The large amount of food that individual growers provide for the auction, makes storage a potential problem, however, auctions occur on a weekly basis, if not more frequently, making this less of a problem.

Auctions also meet many of a retailer's needs. They are able to provide retailers with a large amount of food on a frequent basis, at an affordable price. However, auctions are affected by the seasonality of their location, and will run less frequently or not at all during winter months. Retailers are also limited in the types of produce that the auction house carries-they often specialize in only a few crops, and a large amount of coordination from the auction hall would be required to ensure that there is not an oversupply of one type of produce, which is a current problem with auction food supply [7]. While a retailer may use only one auction hall for its purchases, each grower that provides 
produce functions as a single supplier. The retailer representative would have to negotiate a deal with a different grower, or auctioneer, for each pallet of produce purchased. This means the food is not reliable-it is possible that a retailer could be outbid and unable to purchase food. Since not all auctions require the same GAP certification and insurance, the retailer is put at risk because they may inadvertently purchase food from a grower who is not insured. Once a retailer purchases the food, they must transport it on their own, which is not convenient. Finally, while auctions do provide food at the right price, they are not frequent in places where plain communities are not present, and a drawback of using auction houses as the first intermediary is that there are simply not enough auctions in place to provide for all the food retailers. Plain communities refer to Christian communities distinguished by separation from the world and simple living styles. Examples include Old Order Amish and Mennonite communities.

\subsection{Grower Cooperatives}

In grower cooperatives, several growers pool their resources in order to decrease producer competition and provide for a larger customer base than they would be able alone [22]. This can be very beneficial to growers, as it has been argued that this is a more economically efficient method to deal with monopolies in the current food regime [23]. This is because '[c]ooperatives depend on a group of producers joining forces and, in return, obtaining bargaining power' [22]. However, because growers are working together, their individual identities are lost to the larger identity of the cooperative. They are also unable to negotiate their prices outside of the cooperative umbrella-every grower sells their produce for the same price as other members of the cooperative. Despite this loss of autonomy, there are many advantages for a grower working with a grower's cooperative. For example, they may receive help in transporting their food to the cooperative warehouse, as the cooperative could organize pick up routes and set clear schedules for when specific amounts of produce are needed. A successful grower cooperative would also provide marketing for their grower-members. However, this marketing would serve the cooperative as a whole, not specific growers. Lastly, a grower cooperative would be able to provide the proper amount of storage for the produce, so growers would only need enough storage for in between pick up times.

For a retailer, whether or not a grower cooperative would meet their needs depends on the size of the coop. Some would be able to provide a consistent, large amount of food because they have enough grower-members. If the cooperative covered a large enough geographic area, they also could ensure some protection from seasonality, although typically cooperatives are focused on only one region. They could also ensure that their growers have GAP certification and insurance by fielding who is allowed to become a grower-member. However, grower cooperatives often only focus on one or a couple of items, such as oranges or grapes. This would require a wholesaler to work with multiple cooperatives to obtain enough diversity in their food to satisfy their customers, thus breaking the rule of the lowest number of suppliers possible.

While it may be possible for some grower cooperatives to supply retailers with sustainable, local food, it is not possible for them to provide food-from-somewhere to retailers, because the identities of the specific growers are lost. Furthermore, although it is theoretically possible for a cooperative to provide a retailer with a large, consistent supply of food, it is generally only one type, or perhaps a few types of food per cooperative- not the wide variety of food that a retailer would require. Lastly, the United States simply does not have a large tradition of cooperatives, and an effort to encourage retailers to use grower cooperatives as their suppliers would most likely require an effort to encourage the formation of more cooperatives in addition to inducing a change in the current cooperative system to allow for food-from-somewhere to be produced. This is not a very straightforward way to get food from somewhere into a retailing system. 


\subsection{Food Hubs}

A food hub can be beneficial to growers. While growers still have to accept lower prices for their produce than at a farmers' market, there can be some leeway in the mark-up and price that the grower gets for the produce. Marketing and advertising are done by the food hub, but in general, the specific grower of the produce is not identified. Instead, a common practice is to label food as either local or organic, and to feature some grower profiles on the food-hub's website, but not specifically label the food based on the farm from which it came. This allows growers to maintain some identity, as consumers may be aware that a specific grower is providing food to the food hub, but not know specifically which food came from them. Food storage is the responsibility of the hub, which has a store or a warehouse to keep the produce until it is delivered to or bought by customers. Thus, the grower only needs to be able to store the amount of produce that he or she grows in between deliveries during the growing season. In terms of transportation, the grower generally is responsible for transporting their own food to the hub, although the hub may help them coordinate transportation with other growers.

For a large-scale retailer, a food-hub is generally too small and too focused on local food to function well. A single food-hub typically would not have enough produce to satisfy the needs of a large retailer, meaning that the retailer would need to add more suppliers, or the food hub would have to drastically increase in capacity size. Food hubs are also affected by seasonality because typically they are dealing with food on a local level, although they are able to provide produce for the entire year. While they can be consistent and reliable with their food, this becomes a moot point when one considers that they simply do not provide enough food. As with other methods, hubs do not always require that growers have GAP certification. Lastly, although there are food hubs that deliver food to customers, there are no food hubs that deliver food on the scale that a retailer requires. Thus, a food hub would have to modify its current system, in essence becoming more akin to a conventional corporate food wholesaler, if it were to successfully work with large retailers.

\subsection{Wholesaler}

A wholesaler can function fairly well for a grower, however, it comes with some severe drawbacks. Transportation and storage are provided by the wholesaler, which greatly increases the scope of a grower's customer base. The wholesaler also provides the grower a wide amount of marketing and advertising, which gives the grower a strong endorsement for perspective customers and helps the grower sell produce. However, a wholesaler's advertising faces the same problem as other distribution methods: it often advertises the produce as being from the wholesaler itself, or perhaps a local farm, but not from a specific farm. This means that the grower is unable to maintain an identity with consumers who wish to work with a wholesaler, and any possibility of selling food-from-somewhere is often out of the question. Another serious barrier of the wholesale market is the fact that growers are unable to set their own prices when they work with a wholesaler. Transportation and advertising are not free- the grower must accept lower prices for their produce than they would at any of the other distribution mechanisms, because the wholesaler adds their own mark-up when selling it to their customers. This becomes a problem when qualified growers are forced to compete with industrial food-from-nowhere growers, because they simply cannot afford to sell their food at the same price points as larger farms.

For a retailer, a wholesaler is essentially the only feasible distribution mechanism. Aside from the small-scale accomplishments of the food hub, a wholesaler is the only mechanism to completely meet even one of the retailers' requirements, and in fact, a wholesaler meets all of them. A wholesaler provides the retailer with large quantities of food, reliably, all year-round. All growers who work with wholesalers must have GAP certification and proper insurance, so retailers do not have to worry about accidentally purchasing food from someone who is uninsured. The wholesaler delivers the food to the retailer, so the retailer does not need to worry about transporting their food purchases to their location. Finally, there is only one supplier to the retailer-the wholesaler. Though they will be purchasing food 
that comes from many different growers, it is all mediated through the wholesaler, making purchasing a simple process for the retailer.

\begin{tabular}{|c|c|c|c|c|c|c|}
\hline & & $\begin{array}{c}\text { Farmer's } \\
\text { Market }\end{array}$ & Auction & $\begin{array}{l}\text { Grower } \\
\text { Cooper- } \\
\text { ative }\end{array}$ & Food Hub & $\begin{array}{c}\text { Trad- } \\
\text { itional } \\
\text { Whole- } \\
\text { saler }\end{array}$ \\
\hline \multirow{5}{*}{ 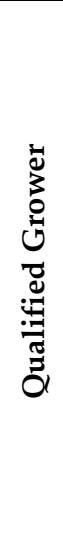 } & $\begin{array}{l}\text { Ability to set their } \\
\text { own prices }\end{array}$ & Yes & No & No & Negotiable & No \\
\hline & $\begin{array}{l}\text { Marketing and } \\
\text { advertising }\end{array}$ & GR & Umbrella & Umbrella & Umbrella & Umbrella \\
\hline & Identity & Yes & Some & No & Some & No \\
\hline & $\begin{array}{l}\text { Transportation of } \\
\text { produce }\end{array}$ & GR & GR & Possibly & GR & Provided \\
\hline & $\begin{array}{l}\text { Amount of food } \\
\text { storage needed }\end{array}$ & $\begin{array}{c}\text { Little } \\
\text { needed }\end{array}$ & Some & Provided & Provided & Provided \\
\hline \multirow{6}{*}{ 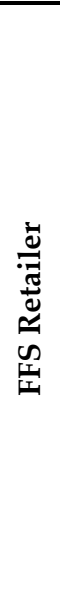 } & $\begin{array}{l}\text { Large quantity of } \\
\text { food }\end{array}$ & No & Yes & Possibly & No & Yes \\
\hline & $\begin{array}{l}\text { Consistent, } \\
\text { reliable food }\end{array}$ & No & No & Possibly & Yes & Yes \\
\hline & Extended seasons & No & No & Possibly & Yes & Yes \\
\hline & $\begin{array}{l}\text { Insurance and } \\
\text { GAP certification }\end{array}$ & Possibly & Possibly & Possibly & Possibly & Yes \\
\hline & $\begin{array}{l}\text { Food delivered to } \\
\text { them }\end{array}$ & No & No & Possibly & No & Yes \\
\hline & Few suppliers & No & No & No & No & Yes \\
\hline
\end{tabular}

Figure 2. Matrix illustrating how various intermediary structures meet, or fail to meet, qualified grower and food-from-somewhere retailers. Green cells are effective, yellow cells are possibly or partially effective, and red cells are ineffective. GR stands for growers' responsibility. Umbrella indicates that the marketing is not for the grower specifically, but for the distributer that the grower is using.

\subsection{The Benevolent Wholesaler}

Figure 2 clearly demonstrates that the only reasonable distribution mechanism for a retailer is a wholesaler. The question then becomes, "How can wholesalers function for qualified growers?" That is, how can growers maintain an identity and the ability to set their own prices in a grower to wholesaler to retailer relationship? In response, our team proposes the idea of a benevolent wholesaler.

In the benevolent wholesaler model, every product from each individual farm will get a stock keeping unit (SKU) number in the wholesaler's product catalogue. Thus, hydroponic lettuce from Farm $A$ and hydroponic lettuce from Farm B will have different SKU numbers, despite the fact that both may be considered broadly "local hydroponic lettuce." This enables retailers to order products from specific farms through their wholesaler. Thus, they could get five heads of lettuce from Farm A, and five from Farm B. The distinction between a conventional wholesaler and a benevolent wholesaler is shown in Figure 3a,b. Figure 3a shows that the grower's identity is lost at the conventional wholesaler's 
warehouse, and is delivered to the retailer as food-from-nowhere. This is represented with the black lines connecting the wholesaler and the retailer. However, Figure $3 \mathrm{~b}$ shows that a benevolent wholesaler maintains food identity in the warehouse with the help of SKU numbers. This allows the food to be delivered as food-from-somewhere, represented by the colored lines, which correspond to the original growers' colors.

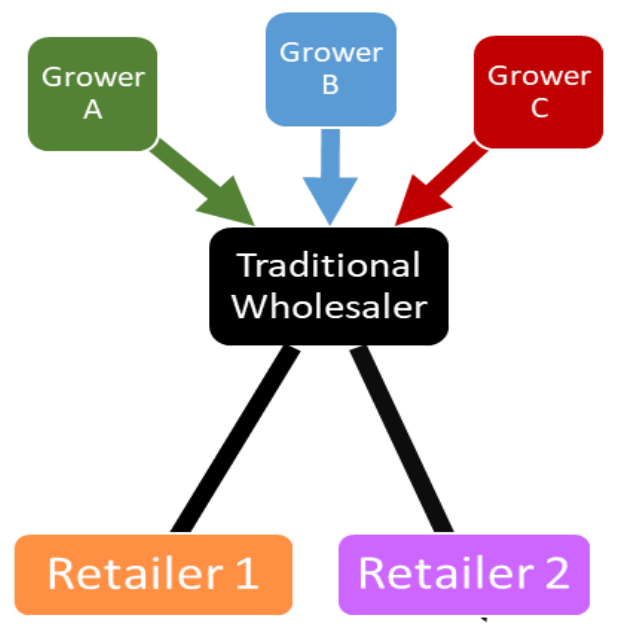

(a)

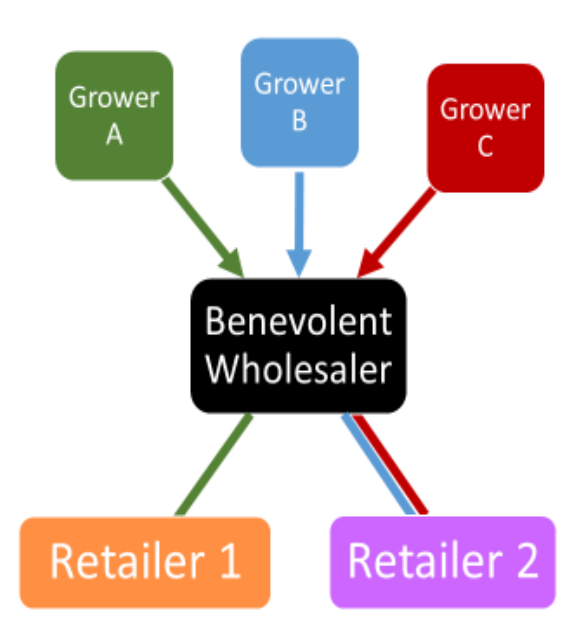

(b)

Figure 3. Two methods of wholesale: (a) traditional wholesale; (b) benevolent wholesale.

With this simple modification in the wholesaler's operational model, the needs of concerned consumers, qualified growers, and responsible retailers are all met. For concerned consumers:

1. Food security: since consumers use large retailers for their food, they can be sure that they will always have access to affordable, fresh, and healthy food.

2. Sustainable and fairly grown food: if retailers only order from qualified growers whenever it is possible, then the food provided to consumers will be sustainable and fairly grown.

3. Food-from-somewhere: because retailers working with concerned consumers will know exactly which farm they are ordering food from on a weekly basis, they will be able to tell consumers where the food came from, thus providing consumers with food-from-somewhere. It would be very simple for retailers to give consumers this information. Two easy methods would be individualized packaging and the creation of an online database of information.

Individualized packaging would provide a quick and easy way for consumers and retailers to know their food's origin. While the benevolent wholesaler could still require uniform sizes and style of packaging, they could allow the growers to display their logo and some basic information about themselves on the packaging. The wholesaler could still require that their logo be affixed the package in addition to the grower's information.

To make the food's somewhere more substantial, benevolent wholesalers and retailers could set up online databases, which provide information about the farms on which the food-from-somewhere was grown. This could provide consumers with more detailed information than a package would provide, or account for instances when food is not displayed to consumers in a package. Consumers would simply have to go online and look up the food's SKU number to get more information. This could also be accomplished with quick response $(\mathrm{QR})$ codes which when scanned, link the consumers to the grower's webpage. The online profiles could include facts about how the food was grown, who grew it, what the farm looks like, or why they should care that they are eating food from Farm A instead of Farm B. Basic databases like this already exist on many food distribution websites, they would just need to be updated to list not only what farms are suppliers to the distributer in general, but what specific food they supply. 
4 Food sovereignty: because consumers will have access to information about their food's origin, they will also have the ability to choose what types of food they want to eat. For example, a consumer wanting to eat primarily organic food may be given access to apples from two different farms. They would be able to research the farms and determine which farm qualifies most as organic, even if neither is officially labeled as such. Furthermore, more growers from the region could get involved with wholesaling (see explanation below), providing the community with a more democratic and self-sustaining food system.

5 Responsible retailer: if a retailer provides the consumer with food-from-somewhere produced by qualified growers, they will be responsible.

The needs of qualified growers are also met:

1. The ability to set their own prices. Perhaps the largest problem that qualified growers face when trying to work with a wholesaler is the low prices that wholesalers offer for the produce. We argue that with a benevolent wholesaler, this would cease to be a problem. Since all produce is tied to a specific farm, it would be very easy to charge different amounts for different items. Each grower could determine what he or she thinks is a fair price for the produce, keeping in mind that the wholesaler will still mark the price up to account for transportation and marketing, and the wholesaler could sell it to the retailer at that price. If Farm A sells their tomatoes for $\$ 1$ more than Farm B, it would be up to the retailer to determine whether the quality of the tomato justifies the higher price.

One may argue that qualified farms, which are essentially small, sustainable, and local when possible, would be unable to compete with distant, unknown farms, if the distant farm offers lower prices. What is being overlooked with this argument is that consumers concerned with food sovereignty are willing to pay more in order to know the origin of their food. If information is seen as a commodity, it holds that the more information consumers are given about a food, the higher price they will be willing to pay for it. This has already proven to be true for local food $[6,14,15,24]$, and we can expect it to hold true for food-from-somewhere.

One may also wonder why a wholesaler would be interested in taking on the risk of the more expensive food-from-somewhere when it would be their loss if the food does not sell. This argument overlooks the fact that wholesalers are profitable by providing food that is demanded by customers. Certainly, if a wholesaler does not have a large customer base interested in accessing food-from-somewhere, then it would not make sense for them to initiate this program. If consumer interest is small, but growing, a wholesaler could begin by selling both food-from-nowhere and food-from-somewhere, and gradually switch to more food-from-somewhere, if/when customer demand grows large enough to support the switch. Apart from a purely economic benefit, increasing the use of food-from-somewhere can increase the consumer trust of and loyalty to the wholesaler, as it has done for retailers selling local food [25].

2 Marketing/advertising. Growers working with a benevolent wholesaler will benefit from the marketing and reputation of the wholesaler. Any retailer using the wholesaler would see the farm as an option for purchasing produce. This would expand their markets far beyond what is possible with distribution methods such as a farmer's market, while still being in a local, or at least regional area. If personalized packaging for the produce is implemented, the packaging will act as advertising for the farm as well.

3 An identity. All products are tied to the farm on which they are grown, thus the growers are able to maintain their identity with consumers. The more information that is relayed to the consumers, the stronger the grower's identity would become. Although we propose that both personalized packaging and an online database be used to substantiate a food's somewhere, we argue that the packaging would provide growers with the most direct control over their identities, as it would be easy to allow a grower to design it themselves. Alternatively, a website would be run by the 
retailer or wholesaler, and would be more user friend if the retailer or wholesaler were in charge of deciding what information should be put up, so the database could be standardized.

4 Transportation for their product. A wholesaler provides transportation for the grower's product. This would not change under the benevolent wholesaler model.

5 Adequate food storage. A benevolent wholesaler would store a grower's produce at a central warehouse until delivery, just as a conventional wholesaler would function.

Lastly, the needs of a retailer are also met. However, because a benevolent wholesaler functions almost identically as a conventional wholesaler for a retailer, it is unnecessary to go through the model point by point, as it would simply be repeating what has already been said about retailer and wholesalers.

\section{Discussion and Conclusions}

We would like to highlight three possible points of contention and refute them. First, it may seem counterintuitive to state that a benevolent wholesaler provides as few suppliers as possible for a retailer, because it breaks the produce down farm by farm. This is in reality a nonissue, because farms are not the direct suppliers for the retailer, but rather the supplier of the benevolent wholesaler. Thus, there is only one supplier for the retailer-the benevolent wholesaler. It would then be the responsibility of the wholesaler to ensure that food from the correct place gets delivered to the right place, at the right time. This should be no problem for a wholesaler.

Next, we list extended seasons and reliable food as a need for retailers, which is why they are often driven to large scale farmers of food-from-nowhere. With a benevolent wholesaler model, retailers could still have extended season and reliable food because many qualified growers do have season-extending strategies such as greenhouses, high tunnels, storage facilities, hydroponic produce, or value-added schemes. For example, in the 1940s, the German immigrant owned greenhouse complexes on the south side of Indianapolis, IN were supplying produce to the city's residents all year-round [26]. The group collectively was the second largest producer of winter lettuce and tomatoes following Cleveland, $\mathrm{OH}$ [26]. A wholesaler could also require qualified growers to declare how much produce they would be able to supply a week or so before the food is picked up. This would give retailers enough time to order the food that they would like, while also giving growers enough time to gauge what crops they can reasonably expect to be able to produce. If on a given week, a storm hits a farm and destroys the crops, the retailers would be able to order from a different qualified grower. If not enough food is available for the retailer's need, the retailer would still have the option to order food-from-nowhere on a supplemental basis.

Finally, creating an inventory management and ordering system for the responsible retailer to put the benevolent wholesaler model into use, and to ensure that it is effective for consumers, is a primary challenge for regional food system logistics [27]. Creating a system of information distribution for consumers, be it signage, an online database, or otherwise, would require a good deal of initial setup, however, such systems already exist and can be modified from existing software. The benefits of adapting to one's processes to maintain chains-of-custody are immense: more qualified growers could become involved in regional, large scale food provision, and consumers reliant on large retailers could be given greater access to more food-from-somewhere than ever before [28]. Ethics aside, if there is a demand for food-from-somewhere, the start-up cost required of the retailer to get the system rolling would be paid for by increased profits and a larger, more loyal, customer base.

\subsection{Implications}

This paper suggests expanding the currently used system of SKUs to create food-from-somewhere within constraints of scale and temporal stability, two necessities for large-scale retailers. Our paper is conceptual not empirical. The implications of this paper center on future empirical and applied research, as opposed to practical actions. The utility of such models, costs and benefits, and problem 
solutions and pitfalls need to be explored and evaluated qualitatively and quantitatively. Early versions of the benevolent wholesaler idea are already in place amongst a few progressive wholesalers and food hubs in Midwestern U.S., and elsewhere. Qualitative approaches that include observations and in depth interviews would foster an understanding of their experience with the practice, providing depth for quantitative analysis across wholesalers to investigate perceived barriers and motives for adopting such an approach. Furthermore, research that focuses on a system that fully integrates producers, wholesalers and retailers, particularly on a large scale, requires sophisticated warehousing and retailing technologies that many do not yet have. Bringing together scholars from varied disciplines, such as food systems studies, economics, business, and informatics would provide a basis for such research.

\subsection{Conclusions}

In conclusion, our paper proposes a relatively simple solution to the problem of getting food-from-somewhere into the large food retailer market. The basic mechanism already exists in a wholesaler's distribution method. A wholesaler picks up food from a farm, takes it to their warehouse, and then delivers it to a retailer. The only thing a benevolent wholesaler would need to change is to expand the SKU system so that every piece of produce from each individual farm gets its own SKU number. This makes a system that already works well for retailers work for qualified growers as well. Retailers will be able to order food from specific farms, and know exactly what farm they are ordering from. When they relay this information to consumers, the food will become food-from-somewhere, and the food's value will rise. This extra value will lead consumers and customers to be willing to pay more for the food, ultimately resulting in higher prices, which small growers can receive for their food. Under this system, a qualified grower can work with a wholesaler while still receiving reasonable prices for their food, and maintaining their identity, and so concerned consumers can have access to food-from-somewhere.

Author Contributions: Conceptualization, formal analysis, and investigation, C.M.H. and D.C.K.; resources, M.E.B. and J.R.F.; data collection, C.M.H., M.E.B., C.C.A., and J.R.F.; writing-original draft preparation, and writing-review and editing, C.M.H., C.C.A., M.E.B., J.R.F., and D.C.K.; supervision, D.C.K.

Funding: This research received no external funding.

Acknowledgments: Carolyn M. Haythorn wishes to acknowledge the generous support of the STARS Program at Indiana University. Daniel C. Knudsen wishes to acknowledge research support from the College of Arts and Sciences at Indiana University. James R. Farmer wishes to acknowledge the Sustainable Food Systems Science program and the Office of the Vice Provost for Research. The authors wish to acknowledge the comments of two anonymous reviewers whose input increased the quality of the paper. Any remaining errors are the sole responsibility of the authors.

Conflicts of Interest: The authors declare no conflict of interest.

\section{References}

1. McMichael, P. A food regime genealogy. J. Peasant Stud. 2009, 36, 139-169. [CrossRef]

2. McMahon, M. Local food: Food sovereignty or myth of alternative consumer sovereignty? In Globalization and Food Sovereignty: Global and Local Change in the New Politics of Food; Andrée, P., Ayres, J., Bosia, M., Massicotte, M.-J., Eds.; University of Toronto Press: Toronto, Japan, 2014; pp. 111-138, ISBN 9781442612280.

3. Andrée, P. Citizens-Farmers: The possibilities and the limits of Australia's emerging alternative food networks. In Globalization and Food Sovereignty: Global and Local Change in the New Politics of Food; Andrée, P., Ayres, J., Bosia, M., Massicotte, M.-J., Eds.; University of Toronto Press: Toronto, ON, Canada, 2014; pp. 141-172, ISBN 9781442612280.

4. Stahlbrand, L. Can values-based food chains advance local and sustainable food systems? Evidence from case studies of university procurement in Canada and the UK. Int. J. Sociol. Agr. Food 2017, 24, 77-95.

5. Forney, J.; Häberli, I. Is "local" enough? New localised food networks in the Swiss dairy industry. Paper presented at the 11th European IFSA Symposium, Berlin, Germany, 1-4 April 2014; Available online: http:/ / www.academia.edu/6709591/Is_local_enough_New_localised_food_networks_in_the_ Swiss_dairy_industry (accessed on 10 October 2018). 
6. Local Food Systems: Concepts, Impacts, and Issues. Available online: https:/ /www.ers.usda.gov/webdocs / publications /46393/7054_err97_1_.pdf?v=0 (accessed on 11 October 2018).

7. Robinson, J.M.; Farmer, J.R. Selling Local: Why Local Food Movements Matter; Indiana University Press: Bloomington, IN, USA, 2017; ISBN 0253026989.

8. Lang, T.; Barling, D. Food security and food sustainability: Reformulating the debate. The Geogr. J. 2012, 178, 313-326. [CrossRef]

9. Barlett, P. Campus sustainable food projects: Critique and engagement. Am. Anthropol. 2011, 113, 101-115. [CrossRef] [PubMed]

10. Breen, S. The mixed political blessing of campus sustainability. Polit. Sci. Polit. 2010, 43, 685-690. [CrossRef]

11. Coleman-Jensen, A.J. U.S. food insecurity status: Toward a refined definition. Soc. Indic. Res. 2010, 95, 215-230. [CrossRef]

12. Farmer, J.R.; Chancellor, C.; Robinson, J.M.; West, S.; Weddell, M. Agrileisure: Farmers' markets, CSAs, and the privilege in eating local. J. Leisure Res. 2014, 46, 313-328. [CrossRef]

13. Campbell, H. Breaking new ground in food regime theory: Corporate environmentalism, ecological feedbacks and the 'food from somewhere' regime? Agric. Hum. Values 2009, 26, 309-319. [CrossRef]

14. Pícha, K.; Navrátil, J.; Švec, R. Preference to local food vs. preference to "national" and regional food. J. Food Prod. Mark. 2018, 24, 125-145. [CrossRef]

15. Engelseth, P. Developing Exchange in Short Local Foods Supply Chains. Int. J. Food Syst. Dyn. 2016, 7, $229-242$.

16. La Via Campesina. Statement network: Our World is not for Sale. 2001. Available online: https:/ viacampesina. org/en/statement-network-qour-world-is-not-for-saleq-owinfs / (accessed on 20 October 2018).

17. Bernard, H.R. Research methods in anthropology: Qualitative and quantitative approaches; Rowman \& Littlefield: Thousand Oaks, CA, USA, 2006.

18. StatsIndiana, Monroe County, Indiana. Available online: http://www.stats.indiana.edu/profiles/profiles. asp?scope_choice=a\&county_changer=18105 (accessed on 7 January 2019).

19. Census, Gov. Quickfacts United States. Available online: https://www.census.gov/quickfacts/ (accessed on 7 January 2019).

20. Donnermeyer, J.F. Doubling Time and Population Increase of the Amish. J. Amish Plain Anabaptist Stud. 2015, 3, 94-109. [CrossRef]

21. Robinson, J.M.; Hartenfeld, J.A. The Farmers' Market Book: Growing Food, Cultivating Community; Indiana University Press: Bloomington, IN, USA, 2007; ISBN 0253219167.

22. Ernst, M.; Woods, T.; Grower cooperatives (Co-ops). Lexington: Cooperative Extension Service, University of Kentucky, College of Agriculture, Food and Environment. Available online: http:/ / www.uky.edu/ccd/ sites/www.uky.edu.ccd/files/co-op.pdf (accessed on 20 October 2018).

23. Knutson, R.D. Cooperatives and the competitive ideal. J. Farm Econ. 1966, 48, 111-121. [CrossRef]

24. Loke, M.K.; Xu, X.; Leung, P.S. Estimating local, organic, and other price premiums of shell eggs in Hawaii. Poultry Sci. 2016, 95, 1050-1055. [CrossRef] [PubMed]

25. Abatekassa, G.; Peterson, H.C. Market access for local food through the conventional food supply chain. Int. Food Agric. Manag. Rev. 2011, 14, 63-82. Available online: https:/ / core.ac.uk/download/pdf/ 6429813. pdf (accessed on 15 January 2019).

26. Trares, R. New Exhibit Looks at Indianapolis' Greenhouse Legacy. Associated Press, 16 January 2019. Available online: https:/ / www.apnews.com/f2d95e86fd69468dbf6f4deacddbbc5d.

27. Mittal, A.; Krejci, C.C.; Craven, T. Logistics Best Practices for Regional Food Systems: A Review. Sustainability 2018, 10, 168. [CrossRef]

28. Barham, J.; Tropp, D.; Enterline, K.; Farbman, J.; Fisk, J.; Kiraly, S. Regional Food Hub Resource Guide; United States Department of Agriculture: Washington, DC, USA, 2012.

(C) 2019 by the authors. Licensee MDPI, Basel, Switzerland. This article is an open access article distributed under the terms and conditions of the Creative Commons Attribution (CC BY) license (http://creativecommons.org/licenses/by/4.0/). 